\title{
MANIFESTATIONS OF ATTENTION IN JUNIOR FEMALE HANDBALL PLAYERS
}

\author{
Cristina ROMILA ${ }^{1 *}$, Sabina MACOVEI ${ }^{1}$, Florentina TONIȚA ${ }^{2}$ \\ ${ }^{1}$ National University of Physical Education and Sport, Faculty of Physical Education and Sport, Bucharest, Romania \\ ${ }^{2}$ Romanian-American University, Faculty of Physical Education, Sport and Kinetotherapy, Bucharest, Romania \\ *Corresponding author: cristina.romila@yahoo.com
}

DOI: 10.35189/iphm.icpesk.2019.40

\begin{abstract}
Knowing the psychological abilities of handball team players is necessary to achieve their characterisation. Our intention is to determine how we can improve the players' motor learning ability and, from this perspective, attention is a valuable component. To be successful, the player must have the ability to keep focused on the executions and actions that follow one after another throughout the game. Distractions caused by various external or internal factors may have a negative impact on the sport performance. It is known that attention has two forms of manifestation: voluntary attention and involuntary attention. Voluntary attention is triggered by a person's interest in a particular activity. Involuntary attention is triggered by various external stimuli whose intervention attracts a person's interest. In this paper, we aimed to investigate the manifestation of attention in junior female handball players using the Roloff Test for distributed and focused attention, the Labyrinth Test for focused attention and the Attention Concentration Test. When applying these tests, all requirements imposed by their authors were respected. The subjects were 38 female handball players born between 2004 and 2007, who were divided into two groups - junior 3 and 4, from the "Sporting Ghimbav" Sports Club. The testing took place on 22 December 2018 and 9 January 2019. The method used consisted in applying the above psychological tests and interpreting the collected results. The conclusions of the research reveal useful information on the way in which the preparation of girl athletes aged 12 to 15 years can be improved.
\end{abstract}

Keywords: attention, psychological testing, handball, juniors.

\section{Introduction}

Attention is the process of exerting mental effort on specific features of the environment or on certain thoughts or activities, while concentration is an attentional process that involves the ability to focus on the task at hand while ignoring distractions (Kremer, Moran, Walker, \& Craig, 2011, p. 103). The ability to concentrate or focus on the task at hand while ignoring distractions is a crucial prerequisite of successful performance in sport. Interviews with top-class sport performers reveal the importance to competitors of being mentally ready for and focused on the specific challenges posed by forthcoming encounters. The word "focused" is often used synonymously with "concentration" to designate a state of effortless absorption which usually accompanies moments of sporting excellence. (Moran, 2016, p. 1)

Attention is a psychological phenomenon achieved through selective activation, concentration and energy orientation towards mental activities. There are two forms of attention: voluntary and involuntary. In the preschool period, the voluntary stage is more influential due to the development of thought and language. Teachers have the task of capturing the involuntary attention of children. With the help of certain methods, they have to stimulate children's interest in such a way that their attention becomes voluntary. (Dumitriu \& Dumitriu, 2004, p. 19)

The duration of attention in preschool and young school children is 10 to 15 minutes at most. Later on, the duration increases to half an hour. As the individual grows up, voluntary attention develops and can be kept over longer periods of time, which is greatly influenced by the subject's interest in the activity carried out. (Clinciu, Cocorada, Luca, Pavalache-Ilie, \& Usaci, 2007, p. 14, pp. 18-22)

It is assumed that, when excitation caused by an intense stimulus (that can be unique) arises in the cerebral cortex, the state of inhibition appears in its proximal areas. For example, in the case of a very loud noise that disrupts our activity, the new stimulus inhibits those that were driving the activity. Thus, attention will shift to the disrupting factor, and the activity can be disturbed. This created phenomenon is called involuntary attention. From the desire to continue an activity in progress, our willpower leads us to stay focused on that activity. Thus, the phenomenon of voluntary attention appears. It is known that attention is based on this mechanism through which the individual can focus on what really interests him or her. (Epuran \& Holdevici, 1980, p. 136)

Specialised books also mention post-voluntary attention, which refers to the trained ability of staying focused. This type of attention is considered to be a skill (Aradavoaice, 2019, p. 26).

Attention, as a psychological ability of the individual, has the role of correcting the information received. It also has the role of adapting the information to the level of thought and responding as appropriately as possible to the received stimuli (Epuran \& Holdevici, 1980, p. 138). 
Handball players must keep their concentration ability throughout the game. Staying focused is the basis of decision-making. Attention can help the player anticipate many actions, such as:

- the decisions made by the opponent, then their exploitation to one's own advantage;

- the decisions made by the referees, by putting the ball back into play in due time, so that the opponent does not have time to react.

Attention must be kept throughout the game; lack of concentration leads to inexplicable mistakes.

According to Epuran, Holdevici and Tonița (2008), attention has the following properties:

a. Stability. It involves staying focused on the action being performed for as long as possible, which occurs when this phenomenon has penetrated into the subject's consciousness.

b. Concentration. It refers to the establishment of tasks. The essence of this property is the intensity with which the subject delimits the crucial action. To maintain focused attention for a long time, athletes make great efforts despite the external factors that may disrupt their activity.

c. Volume. It involves the subject's ability to retain as many things as possible in his or her consciousness.

d. Distribution. It means that the subject can take part in several actions at the same time. For handball players, this property of attention is very important. During the game, a female player must pay attention to teammates, opponents and the coach's instructions. She must execute technical and tactical actions in due time and choose the convenient techniques in order to surprise her opponent in both the attack and defence phases.

e. Switchability. It involves the subject's ability to quickly adapt to changes generated by new assignments. A female handball player must be able to adapt to new game rules or new game systems applied by her own team or the opposing team. (pp. 329-330)

The properties of attention are shown in Figure 1.

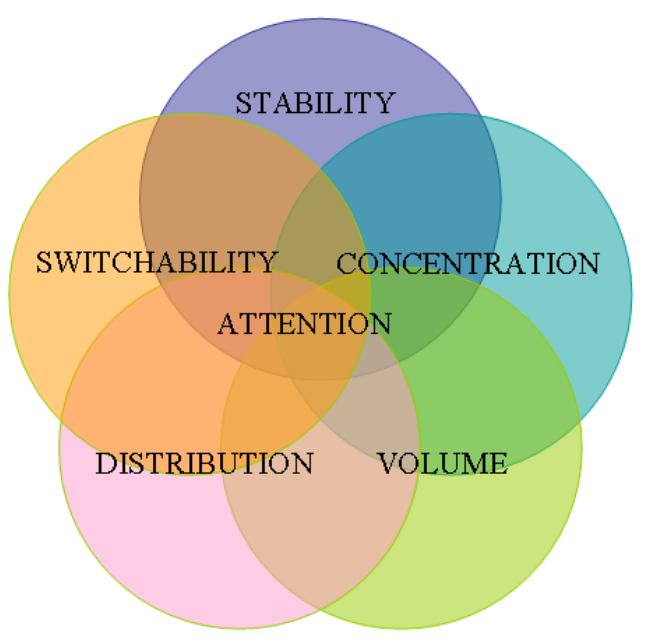

Figure 1. The properties of attention

\section{Premise and purpose}

In this study, we have started from the premise that it is important to know the attention ability of female handball players aged 12 to 15 years. Knowing the players' ability to stay focused over a longer period during the game can provide useful information for the training guidance. We believe that developing the attention and the ability to stay focused for as long as possible is important for the conduct of tactical training.

\section{Material and Methods}

\section{Participants}

The subjects of our study were two groups of female handball players - junior 3, born in 2004 and 2005, and junior 4, born in 2006 and 2007, from the "Sporting Ghimbav" Sports Club. Each group was made up of 19 players, members of the club's representative teams and participants in the National Championships - Junior 3 and 4. The girl athletes are in the first stage of physical training. During this stage, they mainly have to correctly learn 
the elements and techniques of attack and defence. Staying focused in the training process facilitates progress throughout learning. In order to successfully complete this training stage, we consider it necessary to know the players' concentration ability.

\section{Method}

This paper used the test method to investigate the attention of junior female handball players.

The testing took place on 22 December 2018 and 9 January 2019. Prior to the first test and after explaining the study, participants were asked to complete an informed consent form. They were assured of total confidentiality and were allowed to leave the testing at any point. The attention tests used were the Roloff Test for distributed and focused attention, the Labyrinth Test for focused attention and the Attention Concentration Test. When applying these tests, all requirements imposed by their authors were respected.

a. The Roloff Test

It is also called the Semaphore Barrage Test (Table 1), its author being H. Roloff. In this 4-minute test, the subject must discover the identical shapes that are numbered on the sheet and write them at the bottom, where the indicated shapes are placed. The shapes to be found are 7 in number and are similar to the railway semaphores. They have one or two arms that are placed in different positions. The test includes 99 shapes distributed on 9 rows, with 11 shapes on each row. The subject must write the corresponding number, out of the 99 , next to the shape placed at the bottom of the test. Depending on the correct number of shapes found, the test will be interpreted. The correct responses are 36 shapes. To interpret the test, we must relate to the group. Therefore, the subject will be assigned 1 point for each correct response; at the end, the correct responses are added up, and the final score will be related to the standard. (Roloff, 2012)

Table 1. Correct responses to the Roloff Test

\begin{tabular}{cccccccc}
\hline No. of the shape & 1 & 2 & 3 & 4 & 5 & 6 & 7 \\
\hline Correct responses & 4,18, & $8,24,51$ & 14,30, & 2,39, & 12,48, & 5,22, & 16,32, \\
& 36,45, & 58,93 & 44,84 & 77,79, & 86 & 26,61, & 35,63, \\
& $54,71,96$ & & & 98 & & 82,90 & 67,92 \\
\hline
\end{tabular}

b. The Labyrinth Test

This 10-minute test requires the subject to find the correct routes from the beginning to the end. The test includes 25 routes that are differently placed. After completing a route, the subject must write the number corresponding to the chosen route in a checkbox. The test is interpreted depending on the correct responses related to the subject's age. The subject must track the intended routes only visually, without being helped by an external factor, such as pen tracking. Because there are many intersecting lines, the subject may lose the chosen route or may deviate from the initial route. During the test, visual fatigue occurs. Staying focused to find the exact routes from the starting point to the arrival point is essential. At the end, the time taken to complete the test and the correct and wrong responses are assessed. The assessment will be done as follows: the subject is assigned 1 point for each correct response. As regards the corresponding responses, the test author specifies that each route number correlates with the following correct response: 1-16, 2-12, 3-3, 4-20, 5-18, 6-5, 7-23, 8-8, 9-6, 10-10, 11-4, 12-21, $13-1,14-7,15-25,16-19,17-2,18-14,19-24,20-15,21-22,22-9,23-11,24-13,25-17$. Based on the total number of responses received, one can notice which of the subjects have better ability to visually track the activity and the power to stay focused over a longer period of time. The author also provides a ranking: subjects having 25-22 correct responses are rated as "Very good", those having 21-18 correct responses are rated as "Good", those with 17-11 correct responses are rated as "Moderate", and those with 10-0 correct responses are rated as "Poor". (Aradavoaice, 2019, pp. 30-38)

\section{c. The Attention Concentration Test}

This 7-minute test requires the subject to find as many pairs of numbers as possible, the sum of which is 10 . The numbers must be adjacent. There are 25 rows of numbers designated by letters. The subject must find pairs of numbers the sum of which is equal to 10 and underline them. The test interpretation involves summing up the pairs found by the subjects and comparing them with the test author's requirements related to the subject's age.

The test consists in finding as many pairs as possible. It contains 143 pairs. For each pair found, the subject will be assigned 1 point. On test completion, the pairs found are summed up and calculated as follows: for 2-26 
omitted or wrong pairs, the subject is rated as "Very good", for 27-37 omitted or wrong pairs, the subject is rated as "Good", for 38-48 omitted or wrong pairs, the subject is rated as "Moderate", and for 49-143 omitted or wrong pairs, the subject is rated as "Poor".

According to Aradavoaice (2019), the interpretation of the resulting ratings indicates the following:

- for athletes rated as "Very good": they manage to stay focused even if the activity is not interesting and creates a state of boredom;

- for athletes rated as "Good": they have the ability to keep their attention focused on what they are interested in;

- for athletes rated as "Moderate": this type of attention is common to most people; the levels are normal, and athletes are encouraged to increase their ability to focus through the knowledge they can acquire and to eliminate the possible distracting factors;

- for athletes rated as "Poor": they are not focused and are constantly warned about this. Because they are very easily distracted from the activity carried out, they are encouraged to focus on it. If not, it is important for them to find out if they really want to do what they are asked to do or if they disagree with what they are asked to do or how important that thing is. (pp. 24-29)

\section{Results}

The results obtained by the Junior 3 group are shown in Tables 2 and 3 (Central tendency - Junior 3 group).

Table 2. Results obtained in the attention tests by the Junior 3 Team from the "Sporting Ghimbav" Sports Club

\begin{tabular}{|c|c|c|c|c|c|c|c|c|}
\hline \multirow[b]{2}{*}{$\begin{array}{c}\text { Item } \\
\text { no. }\end{array}$} & \multicolumn{2}{|c|}{ Player data } & \multicolumn{2}{|c|}{ Roloff Test } & \multicolumn{2}{|c|}{ Labyrinth Test } & \multicolumn{2}{|c|}{ Attention Concentration Test } \\
\hline & $\begin{array}{l}\text { Name } \\
\text { initials }\end{array}$ & $\begin{array}{c}\text { Year of } \\
\text { birth }\end{array}$ & $\begin{array}{c}\text { No. of } \\
\text { correct } \\
\text { responses }\end{array}$ & $\begin{array}{c}\text { No. of } \\
\text { missing } \\
\text { responses }\end{array}$ & $\begin{array}{c}\text { No. of } \\
\text { correct } \\
\text { responses }\end{array}$ & $\begin{array}{l}\text { No. of missing/ } \\
\text { wrong } \\
\text { responses }\end{array}$ & $\begin{array}{l}\text { No. of correct } \\
\text { responses }\end{array}$ & $\begin{array}{l}\text { No. of missing } \\
\text { responses }\end{array}$ \\
\hline 1 & L.A. & 2004 & 24 & 12 & 8 & 17 & 76 & 67 \\
\hline 2 & S.M. & 2004 & 25 & 11 & 14 & 11 & 111 & 32 \\
\hline 3 & S.C.I. & 2004 & 23 & 13 & 12 & 13 & 100 & 43 \\
\hline 4 & M.E. & 2004 & 28 & 8 & 18 & 7 & 111 & 32 \\
\hline 5 & L.A. & 2004 & 34 & 2 & 17 & 8 & 121 & 22 \\
\hline 6 & M.C. & 2004 & 28 & 8 & 14 & 11 & 94 & 49 \\
\hline 7 & C.T. & 2004 & 31 & 5 & 9 & 16 & 89 & 54 \\
\hline 8 & I.F. & 2004 & 27 & 9 & 8 & 17 & 96 & 47 \\
\hline 9 & M.D. & 2004 & 24 & 12 & 13 & 12 & 85 & 58 \\
\hline 10 & A.V. & 2004 & 31 & 5 & 6 & 19 & 67 & 76 \\
\hline 11 & A.G. & 2004 & 28 & 8 & 16 & 9 & 95 & 48 \\
\hline 12 & B.R. & 2004 & 32 & 4 & 13 & 12 & 110 & 33 \\
\hline 13 & L.F. & 2004 & 35 & 2 & 23 & 2 & 135 & 8 \\
\hline 14 & P.A. & 2005 & 29 & 7 & 8 & 17 & 94 & 49 \\
\hline 15 & F.G. & 2005 & 8 & 28 & 7 & 18 & 77 & 66 \\
\hline 16 & V.T. & 2005 & 30 & 6 & 10 & 15 & 133 & 10 \\
\hline 17 & D.M. & 2005 & 13 & 13 & 6 & 19 & 59 & 84 \\
\hline 18 & F.L.A. & 2005 & 31 & 5 & 12 & 13 & 74 & 69 \\
\hline 19 & P.L. & 2005 & 26 & 10 & 19 & 6 & 70 & 73 \\
\hline
\end{tabular}

Table 3. Central tendency - Junior 3 group

\begin{tabular}{lccc}
\hline \multicolumn{1}{c}{ Statistical indicators } & Roloff Test & Labyrinth Test & Attention Concentration Test \\
\hline Mean & 23.6 & 10.6 & 89.9 \\
Median & 28 & 12 & 94 \\
Std. deviation & 6.5 & 4.7 & 21.1 \\
Coefficient of variation $(\%)$ & $27 \%$ & $44 \%$ & $23 \%$ \\
Minimum & 8 & 6 & 59 \\
\hline
\end{tabular}


International Proceedings of Human Motricity/ ICPESK 2019

Supplementary Issue of Discobolul - Physical Education, Sport and Kinetotherapy Journal, 2019

\begin{tabular}{lccc}
\hline Maximum & 35 & 23 & 135 \\
Range & 27 & 17 & 76 \\
\hline
\end{tabular}

In the Roloff Test applied to Junior 3 players, it can be noted that the number of correct responses is very high (Figure 2). The mean of correct responses is 23.6. Most female athletes are rated as "Good" towards "Very good". This indicates that, if time is short, they can keep their attention. The junior 3 group shows a moderate homogeneity of $27 \%$.

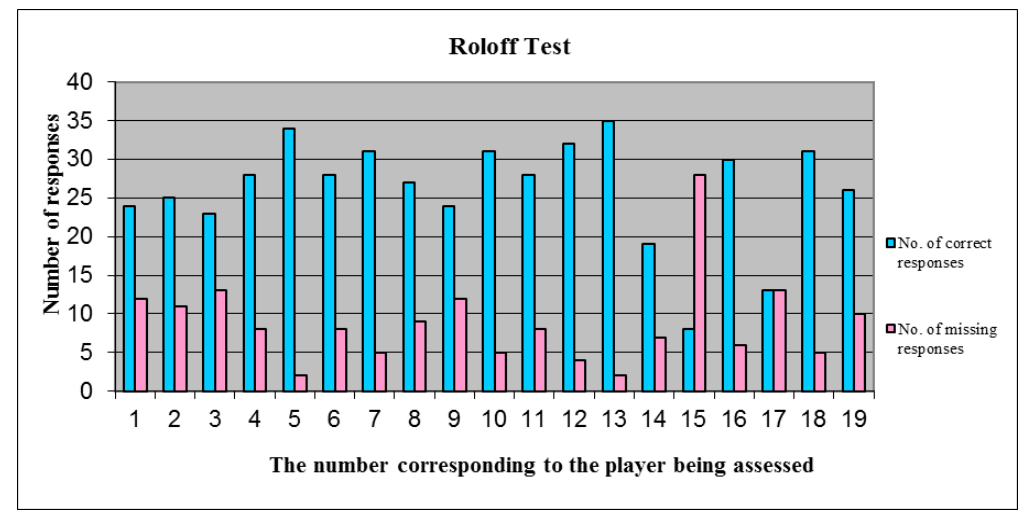

Figure 2. Responses to the Roloff Test received from the Junior 3 Team

In the Labyrinth Test, the results show that the female players have scored a very low number of correct responses (Figure 3). The mean of correct responses is 10.6. Most athletes are rated as "Moderate". These results indicate that staying focused over a longer period of time is a greater demand for them. The coefficient of variation reveals a lack of homogeneity $(44 \%)$.

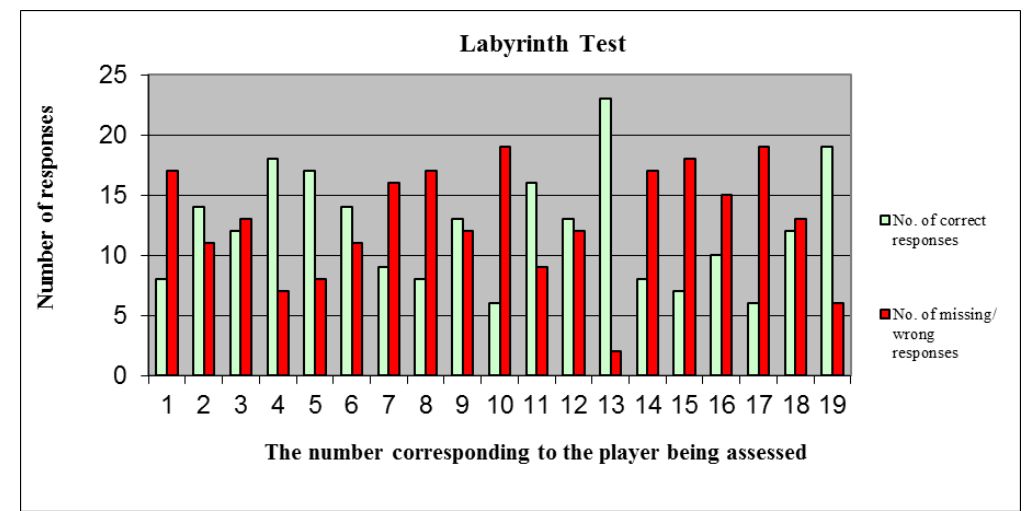

Figure 3. Responses to the Labyrinth Test received from the Junior 3 Team

In the Attention Concentration Test, the correct responses received from most female players are more numerous than the missing ones (Figure 4). Thus, only 3 girls have more missing responses than the correct ones. The mean of correct responses is 89 , with a minimum of 59 and maximum of 135 . Most athletes are rated as "Moderate" and "Good". The coefficient of variation shows a moderate homogeneity of the group. 


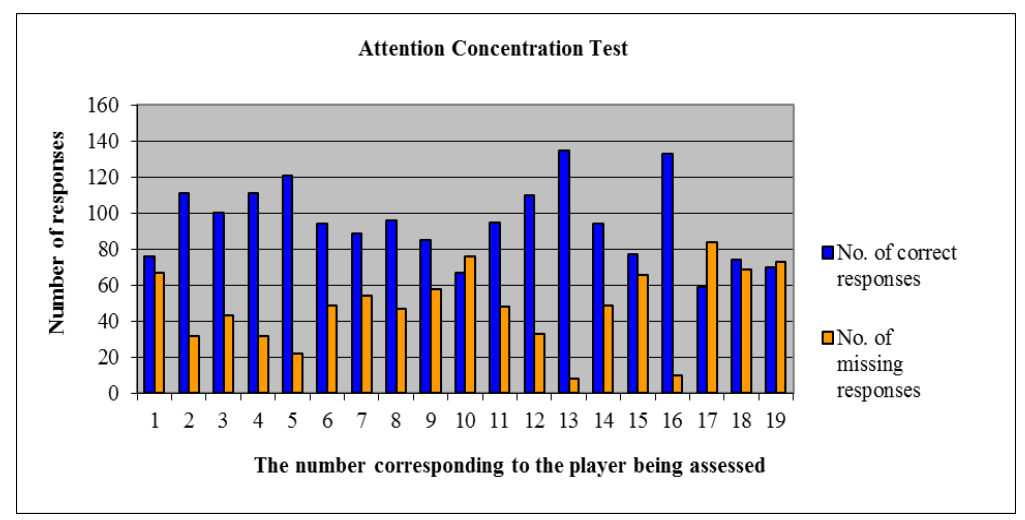

Figure 4. Responses to the Attention Concentration Test received from the Junior 3 Team

It can be seen that most girl athletes have encountered difficulties with the Labyrinth Test, which is revealed by the great number of missing or wrong responses. This test had the longest completion time and, according to the responses received, focused attention is lower in female athletes. We note that, in all three tests, players have almost similar results. The differences recorded for each of them are very small from one test to another. For instance, athlete 13 achieved very good results in all three tests; athlete 5 was rated as "Good" in two tests and "Moderate" in one test; athletes 15 and 17 had more wrong than correct responses.

According to the responses received, there is a need to develop the girls' ability to maintain focused attention over a longer period of time.

For the Junior 4 group, the results are shown in Tables 4 and 5 (Central tendency - Junior 4 group).

Table 4. Results obtained in the attention tests by the Junior 4 Team from the "Sporting Ghimbav" Sports Club

\begin{tabular}{|c|c|c|c|c|c|c|c|c|}
\hline \multirow[b]{2}{*}{$\begin{array}{c}\text { Item } \\
\text { no. }\end{array}$} & \multicolumn{2}{|c|}{ Player data } & \multicolumn{2}{|c|}{ Roloff Test } & \multicolumn{2}{|c|}{ Labyrinth Test } & \multicolumn{2}{|c|}{ Attention Concentration Test } \\
\hline & $\begin{array}{l}\text { Name } \\
\text { initials }\end{array}$ & $\begin{array}{c}\text { Year of } \\
\text { birth }\end{array}$ & $\begin{array}{c}\text { No. of } \\
\text { correct } \\
\text { responses }\end{array}$ & $\begin{array}{c}\text { No. of } \\
\text { missing } \\
\text { responses }\end{array}$ & $\begin{array}{c}\text { No. of } \\
\text { correct } \\
\text { responses }\end{array}$ & $\begin{array}{l}\text { No. of missing/ } \\
\text { wrong responses }\end{array}$ & $\begin{array}{c}\text { No. of correct } \\
\text { responses }\end{array}$ & $\begin{array}{c}\text { No. of missing } \\
\text { responses }\end{array}$ \\
\hline 1 & F.M. & 2006 & 33 & 3 & 12 & 13 & 68 & 75 \\
\hline 2 & M.S.M. & 2006 & 24 & 12 & 6 & 19 & 96 & 47 \\
\hline 3 & S.A. & 2007 & 27 & 9 & 9 & 16 & 73 & 70 \\
\hline 4 & N.A. & 2006 & 27 & 9 & 14 & 11 & 90 & 53 \\
\hline 5 & M.A.I. & 2007 & 26 & 10 & 14 & 11 & 76 & 67 \\
\hline 6 & R.D.A. & 2007 & 25 & 11 & 18 & 7 & 110 & 33 \\
\hline 7 & I.A. & 2007 & 17 & 19 & 7 & 18 & 10 & 133 \\
\hline 8 & E.C.M. & 2006 & 15 & 21 & 11 & 14 & 75 & 68 \\
\hline 9 & R.D. & 2006 & 22 & 14 & 16 & 9 & 60 & 83 \\
\hline 10 & A.P.I. & 2007 & 29 & 7 & 11 & 14 & 93 & 50 \\
\hline 11 & A.A. & 2007 & 30 & 6 & 16 & 9 & 92 & 51 \\
\hline 12 & D.A. & 2006 & 23 & 13 & 6 & 19 & 88 & 55 \\
\hline 13 & S.L. & 2007 & 24 & 12 & 13 & 12 & 69 & 74 \\
\hline 14 & D.T. & 2007 & 27 & 9 & 20 & 5 & 86 & 57 \\
\hline 15 & T.A. & 2006 & 33 & 3 & 25 & 0 & 120 & 23 \\
\hline 16 & C.I. & 2006 & 23 & 13 & 19 & 6 & 60 & 83 \\
\hline 17 & D.I. & 2007 & 20 & 16 & 18 & 7 & 100 & 43 \\
\hline 18 & S.A.M. & 2007 & 19 & 16 & 6 & 19 & 36 & 107 \\
\hline 19 & R.R. & 2007 & 16 & 20 & 14 & 11 & 70 & 73 \\
\hline
\end{tabular}

Table 5. Central tendency - Junior 4 group

\begin{tabular}{lccc}
\hline \multicolumn{1}{c}{ Statistical indicators } & Roloff Test & Labyrinth Test & Attention Concentration Test \\
\hline Mean & 23.0 & 11.2 & 56.2 \\
Median & 24 & 14 & 76 \\
\hline
\end{tabular}


International Proceedings of Human Motricity/ ICPESK 2019

Supplementary Issue of Discobolul - Physical Education, Sport and Kinetotherapy Journal, 2019

\begin{tabular}{lccc}
\hline Std. deviation & 5.1 & 5.2 & 24.8 \\
Coefficient of variation (\%) & $22 \%$ & $46 \%$ & $44 \%$ \\
Minimum & 15 & 6 & 10 \\
Maximum & 33 & 25 & 120 \\
Range & 18 & 19 & 110 \\
\hline
\end{tabular}

As in the case of Junior 3 players, it can be noted that the number of correct responses to the Roloff Test from the Junior 4 players is very high (Figure 5). The mean of correct responses is 23.0, and most girl athletes are rated as "Good" towards "Very good". The coefficient of variation shows a moderate homogeneity of the group.

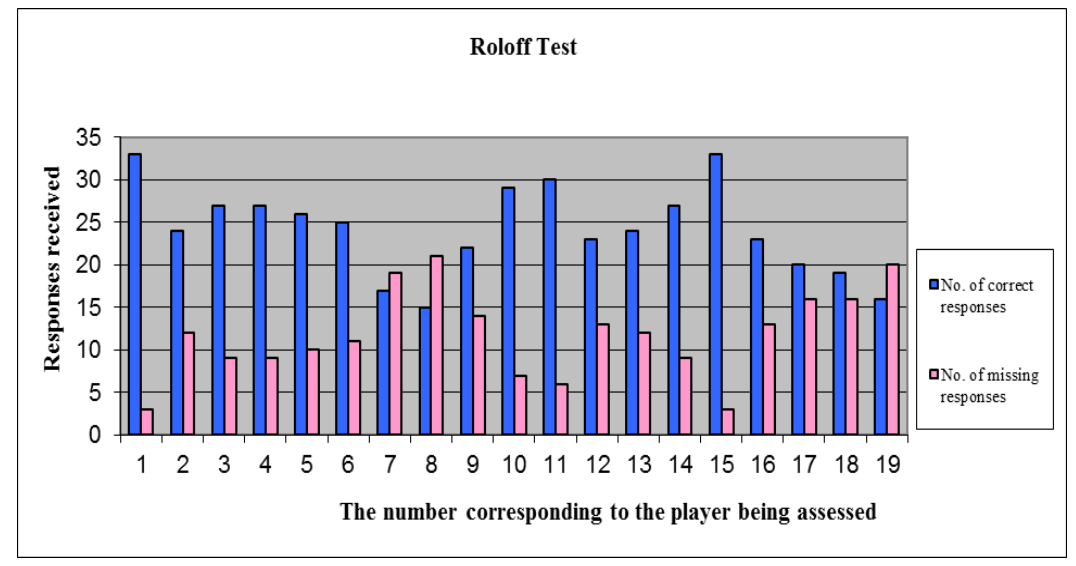

Figure 5. Responses to the Roloff Test received from the Junior 4 Team

In the Labyrinth Test (Figure 6), the average of correct responses is 11.2, and a large part of the Junior 4 players are rated as "Moderate". As in the case of the junior 3 group, the coefficient of variation reveals a lack of homogeneity (46\%). We interpret this aspect by the fact that the age of junior 4 athletes is not conducive to maintaining their focused attention over a longer period of time.

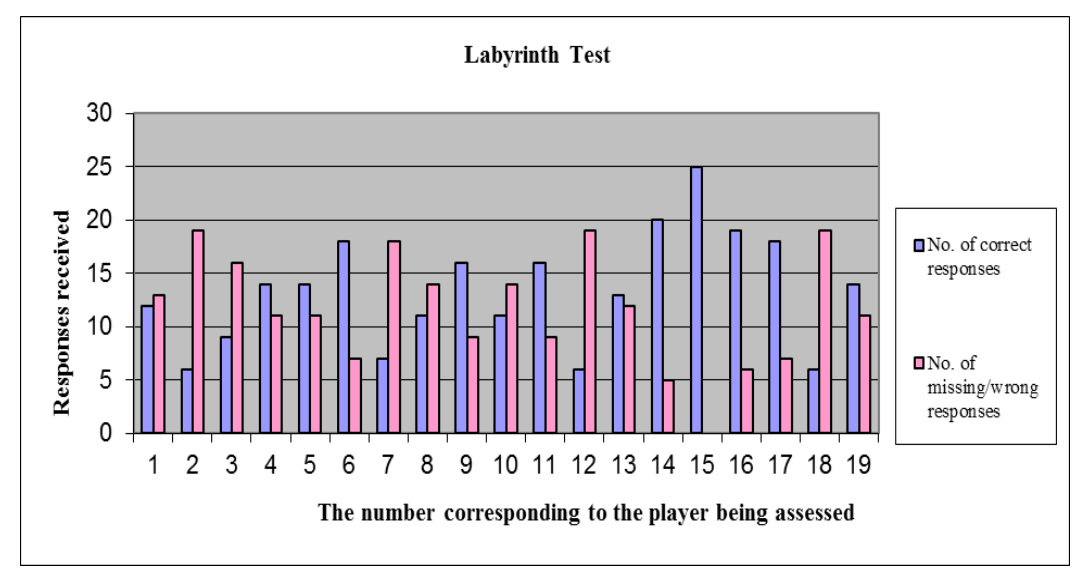

Figure 6. Responses to the Labyrinth Test received from the Junior 4 Team

In the Attention Concentration Test (Figure 7) applied to Junior 4 players, the correct responses received from most of them are more numerous than the missing ones, with the exception of 8 girl athletes. The mean of correct responses is 56.2, and the players are rated as "Poor", "Moderate" and "Good". However, compared to the results achieved by the junior 3 group, the coefficient of variation shows a lack of homogeneity. The results can also be explained by the younger age of players. 


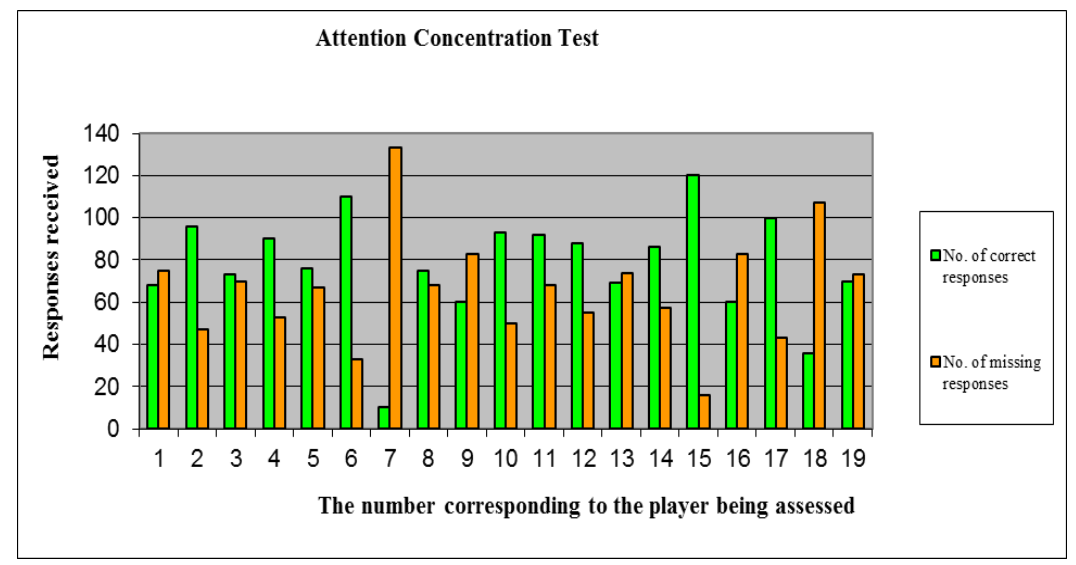

Figure 7. Responses to the Attention Concentration Test received from the Junior 4 Team

\section{Conclusion}

Applying attention tests to junior female players is very useful to identify each one's ability to maintain focused attention over a longer period of time. Each age stage is different due to the levels of experience and preparation gained by the athlete.

From the responses received to these tests, we can draw the following conclusions:

- On average, more correct responses were received from older players (junior 3) compared to younger players, the largest difference being recorded in the Attention Concentration Test.

- In the Roloff Test, which lasted 4 minutes, the girl athletes managed to find most correct responses, followed by the Attention Concentration Test, which lasted 7 minutes, and the fewest correct responses were recorded in the Labyrinth Test, which lasted 10 minutes. This indicates that the duration of a test may be very important, the female players having to keep their focused attention over a longer period of time.

- Players with very good responses to a test were constant and also had good responses to the other two tests, and conversely: players with less good responses to a test had poor responses to the other tests; there were also exceptions, namely a girl athlete recorded very good results in a single test. We can conclude that the investigated athletes are constant: if they are able to respond well to a test, they can stay focused in the next test too.

- Identifying the female players who have good attention ability and those whose attention ability is less developed can provide coaches with useful information to customise their training sessions. After the identification of these athletes, it is necessary to find solutions to keep their focused attention.

The results of our research are consistent with the literature data attesting that attention has great flexibility in its development (Moran, Campbell, \& Toner, 2019, p. 11). In fact, the manifestation of attention encompasses specific dimensions, according to the requirements of each sports discipline (Predoiu, Dinuță, \& Gavojdea, 2016, p. 62). Some recent research shows that athletes practicing individual disciplines, such as gymnastics, tennis or karate, have better ability to focus their attention than athletes involved in team games (Păunescu, Mitrache, Grigore, \& Predoiu, 2014).

However, in sports games, divided attention is essential. Actually, the cognitive aspects relating to attention and anticipation are thought to be defining, from a psychological perspective, for the training of performance handball teams (Wagner, Finkenzeller, Würth, \& von Duvillard, 2014).

The data recorded in the attention tests can help us in the instructive process. Following the responses received, we can see if they manifest identically in the sports training. The study provides an indication of the direction that future research may wish to pursue. By determining the athletes' attention ability, they can be advised to use the most effective and suitable strategy in order to achieve the best possible performance.

\section{Authors' Contributions}

All authors contributed equally to this article and should be considered as main authors. 


\section{References}

Aradavoaice, Gh. (2019). Teste psihologice de autoevaluare [Psychological self-assessment tests]. Retrieved from https://ro.scribd.com/doc/31570931/Gheorghe-Aradavoaice-Teste-Psihologice-de-Autoevaluare

Clinciu, A. I., Cocorada, E., Luca, R. M., Pavalache-Ilie, M., \& Usaci, D. (2007). Psihologie educatională [Educational psychology]. Braşov: Editura Universităţii Transilvania.

Dumitriu, G., \& Dumitriu, C. (2004). Psihopedagogie: Curriculum-suport pentru examenele de definitivat şi gradul II în învăţământ [Psychopedagogy: Support-curriculum for obtaining the permanent teacher certification and the $2^{\text {nd }}$ teaching degree]. Bucureşti: Editura Didactică şi Pedagogică, R.A.

Epuran, M., \& Holdevici, I. (1980). Compendiu de psihologie pentru antrenori [Compendium of psychology for coaches]. Bucureşti: Sport-Turism.

Epuran, M., Holdevici, I., \& Tonița, F. (2008). Psihologia sportului de performanță - Teorie și practică [The psychology of performance sport - Theory and practice]. Bucureşti: FEST.

Kremer, J., Moran, A., Walker, G., \& Craig, C. (2011). Attention and concentration. In Key concepts in sport psychology (pp. 103-108). London: Sage. http://dx.doi.org/10.4135/9781446288702.n19

Moran, A. P. (2016). The psychology of concentration in sport performers: A cognitive analysis. Psychology Press.

Moran, A., Campbell, M., \& Toner, J. (2019). Exploring the cognitive mechanisms of expertise in sport: Progress and prospects. Psychology of Sport \& Exercise, 42, 8-15. https://doi.org/10.1016/j.psychsport.2018.12.019

Păunescu, M., Mitrache, G., Grigore, V., \& Predoiu, R. (2014). Use of computer technology in evaluating the concentration and mobility of attention. In I. Roceanu (Ed.), Proceedings of the 9th International Scientific Conference "eLearning \& Software for Education" (Vol. 3, pp. 137-142). Bucharest: Editura Universității Naționale de Apărare "Carol I". DOI: 10.12753/2066-026X-13-237

Predoiu, A., Dinuţă, Gh., \& Gavojdea, A.-M. (2016). Spatial orientation and attention at 12 years old artistic gymnasts and handball players. Romanian Journal of Experimental and Applied Psychology, 7(1), 61-65. DOI: 10.15303/rjeap.2016.si1.a12

Roloff, H. (2012). Proba de Baraj Semafoare [The Semaphore Barrage Test]. Retrieved from https://dokumen.tips/documents/proba-de-baraj-semafoare-manual-56b8409ddeaf1.html

Wagner, H., Finkenzeller, T., Würth, S., \& von Duvillard, S. P. (2014). Individual and team performance in teamhandball: A review. Journal of Sports Science \& Medicine, 13(4), 808-816. Retrieved from https://www.ncbi.nlm.nih.gov/pmc/articles/PMC4234950/ 